\section{Hepatitis Awareness Month and Testing Day — May 2017}

May 19th is National Hepatitis Testing Day in the United States to emphasize the importance of testing persons at risk for hepatitis $\mathrm{B}$ virus (HBV) and hepatitis $\mathrm{C}$ virus (HCV) infections, most of whom are unaware of their infection status. Recognizing the effectiveness of testing and other preventive and treatment measures, the National Academies of Science, Engineering, and Medicine recently set goals for the elimination of HBV and HCV as public health threats in the United States.*

$\mathrm{HCV}$ is the most common form of viral hepatitis in the United States and in 2013, accounted for approximately 19,000 deaths per year, a number that was greater than that of 60 other nationally notifiable infectious diseases combined (1). During 2010-2015, HCV incidence increased by $294 \%$ with the highest rates among young persons who inject drugs (PWID). ${ }^{\dagger}$

This issue of MMWR includes two reports describing trends in HCV incidence and the availability of HCV prevention and treatment services that stop transmission. In the first report, only three states had comprehensive laws providing full access to $\mathrm{HCV}$ preventive and treatment services for PWID. The second report estimates rates of $\mathrm{HCV}$ infection among pregnant women in the United States and Tennessee; in the United States, HCV rates nearly doubled during 2009-2014, and in Tennessee, the rate in 2014 was approximately three times the national rate. Data from both reports emphasize the importance of viral hepatitis surveillance to identify communities at risk for $\mathrm{HCV}$ and public health policies that make available interventions that prevent HCV transmission and disease.

*http://www.nationalacademies.org/hmd/reports/2017/national-strategyfor-the-elimination-of-hepatitis-b-and-c.aspx.

${ }^{\dagger}$ https://www.cdc.gov/hepatitis/statistics/index.htm.

\section{Reference}

1. Ly KN, Hughes EM, Jiles RB, Holmberg SD. Rising mortality associated with hepatitis C virus in the United States, 2003-2013. Clin Infect Dis 2016;62:1287-8. https://doi.org/10.1093/cid/ciw111

\section{State HCV Incidence and Policies Related to HCV Preventive and Treatment Services for Persons Who Inject Drugs - United States, 2015-2016}

Cecily A. Campbell, JD ${ }^{1}$, Lauren Canary, $\mathrm{MPH}^{1}$; Nicole Smith, $\mathrm{PhD}^{1}$; Eyasu Teshale, $\mathrm{MD}^{1}$; A. Blythe Ryerson, $\mathrm{PhD}^{1}$; John W. Ward, $\mathrm{MD}^{1}$

Hepatitis $\mathrm{C}$ is associated with more deaths in the United States than 60 other infectious diseases reported to CDC combined. Despite curative hepatitis $\mathrm{C}$ virus (HCV) therapies and known preventive measures to interrupt transmission, new $\mathrm{HCV}$ infections have increased in recent years $(1,2)$. Injection drug use is the primary risk factor for new HCV infections (2). One potential strategy to decrease the prevalence of $\mathrm{HCV}$ is to create and strengthen public health laws and policies aimed specifically at reducing transmission risks among persons who inject drugs. To evaluate factors affecting access to HCV preventive and treatment services, CDC assessed state laws governing access to safe injection equipment and Medicaid policies related

\section{INSIDE}

470 Hepatitis C Virus Infection Among Women Giving Birth - Tennessee and United States, 2009-2014

474 Current and Binge Drinking Among High School Students — United States, 1991-2015

479 CDC Grand Rounds: Public Health Strategies to Prevent and Treat Strokes

482 Recommendations of the Advisory Committee on Immunization Practices for Use of Cholera Vaccine

486 Notes from the Field: Severe Human Metapneumovirus Infections - North Dakota, 2016

489 Announcements

491 QuickStats

Continuing Education examination available at https://www.cdc.gov/mmwr/cme/conted_info.html\#weekly.

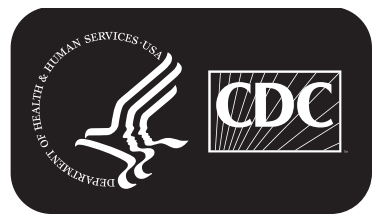

U.S. Department of Health and Human Services Centers for Disease Control and Prevention 